\title{
Editorial: Good bye exams, hello eportfolio
}

\author{
Orna Farrell ${ }^{* 1}$ \\ Karen Buckley ${ }^{2}$ \\ Lisa Donaldson ${ }^{3}$ \\ Tom Farrelly ${ }^{4}$ \\ ${ }^{1}$ Dublin City University \\ ${ }^{2}$ Dublin City University \\ ${ }^{3}$ Dublin City University \\ ${ }^{4}$ Munster Technological University
}

\section{Introduction}

The aim of this special issue of the Irish Journal of Technology Enhanced Learning is to explore eportfolio in Ireland and further afield. An eportfolio can be a tool or technology, a practice, a pedagogical model, an assessment method and a framework for learning (Chen \& Black, 2010). There is growing interest in Ireland in the affordances of eportfolio and their potential to positively impact student learning and achievement. However, there was a dearth of empirical research on eportfolio practice in the context of the Irish educational system. This special issue on eportfolio aims to fill this gap in the literature, and enable us to better appreciate eportfolio practice and ground this in research.

Women scholars have been disproportionately affected by the Covid-19 pandemic, in this special issue, the editorial team acknowledged and identified actions we could take to help to mitigate such effects on women scholars. These supports paid off; $83 \%$ of the authors in this issue are women.

Creating a special issue of a journal takes community and hard work. The editors thank the IJTEL team, and the authors for their support and perseverance during a challenging time. Through this special issue of eportfolio, we are proud to add to the scholarship on eportfolio and to support women scholars during the Covid-19 pandemic.

\section{Eportfolio: what have we learned?}

The articles in this special issue were published in two batches, the first five in July 2021 and the second batch in December 2021, there are fifteen articles in total. The range of affordances that eportfolios can provide, such as: assessment, reflective practice, showcasing and evidencing of work and a vehicle for professional development (Farrell, 2020; Nagle et al. 2019) are all evident in this issue. While the use and availability of eportfolios certainly predates the Covid-19 pandemic, the call to maximise the opportunities that educational technology platforms can provide went into overdrive since March 2020. The range of responses evident in this issue certainly suggest that higher education staff have risen to that challenge.

Laura Costelloe, Mary Immaculate College, discussed the potential of eportfolio to support professional learning highlighting their flexibility but cautioned however that it is a time consuming process for which support is required (Costelloe, 2021). The theme of eportfolio for professional 
learning was further explored by Marie O'Neill and Ken McCarthy in relation to the National Forum for the Enhancement of Teaching and Learning's PACT digital badge. Similarly, Kate Dunne and Pauline Logue investigated the effectiveness of eportfolio as an assessment approach for a postgraduate professional learning module.

The potential of eportfolio was also emphasised by James Gallen at Dublin City University. He shared how they contributed to the development of student critical awareness of social justice and supported links between course content and social justice issues. Gallen highlights the 'joy' of reviewing students' personal reflections with the creative inclusion of multimedia (Gallen, 2021). Reflection is also a key theme in the article by Ruth McManus, also from Dublin City University. She shared lessons learned in reflective journaling with Geography students, in particular referencing how reflective journals can benefit both students and educators through their use as a tool to share learning experiences, particularly useful as a 'safe space' in pandemic times (McManus, 2021). Continuing the theme of reflective learning and eportfolio Rita Zuba Prokopetz explored the use of reflective eportfolio projects with English language learners at Red River College in Canada. She found that the eportfolio projects, developed by the students individually and in collaboration with their peers, fostered engagement and feedback

Hazel Farrell, Waterford Institute of Technology, again picks up on the theme of creativity and eportfolios and their use as a multifunctional tool for final year Music students. The flexibility of the eportfolio platform facilitated a creative space for students to showcase their achievements which also then supported the marketing of the programme (Farrell, 2021). The practice report of Christine Ziegelbauer and Barbara D'Errico from the University of Konstanz again returns to the concept of 'potential'. In this case, she discusses that a well-supported eportfolio programme enables the display of the learners' potential in a teacher education programme (Ziegelbauer \& D'Errico, 2021).

Aine Doherty and Chris McLaughlin's article highlights how eportfolios have translated so well to an area that traditionally has had a strong emphasis on face-to-face teaching; apprenticeships. We are often told that portfolios, electronic or otherwise, present a very useful vehicle for reflective practice. But that can sometimes beg the question: 'what does that look like in practice?' Sandra Flynn and Fiona Levie's proposed model - reflective learning portfolio-in-practice offers one possible practical response. Speaking of proposed solutions with a strong practice application, Tracey Harrington and Sandra O'Neill's article is a clarion call to the entire Irish nursing profession (and in particular the Irish Nursing \& Midwifery Board) to embrace the possibilities presented by the adoption of nationally agreed eportfolio platform for registration and revalidation.

The issue features two articles focused on the eportfolio in the discipline of business studies. Roisin Donnelly reports on an initiative which explored the embedding of ePortfolios in programme-level assessment across the College of Business in the Technological University of Dublin. Roisin Lyons, Ciara Lynch and Eoghan McConalogue's report on the use of the eportfolio within a large class (over 600) in enterprise education in Dublin City University is an excellent illustration of how the size of class should not dissuade lecturers from adopting innovative assessment and feedback practices.

Two national studies of eportfolio practice feature in this issue, one based in Canada and the other in Ireland. Debra Hoven, Pamela Walsh, Rima Al-Tawil and Rita Zuba Prokopetz from Athabasca University investigated Canadian higher education eportfolio practice and explored how faculty or instructors of such eportfolio activities were selected and what professional development (PD) opportunities were available to them. In the Irish context, the Eportfolio Ireland steering group Orna 
Farrell, Karen Buckley, Lisa Donaldson and Tom Farrelly conducted a landscape snapshot of eportfolio practice and technologies across Irish Higher Education Institutes.

A number of interesting patterns are evident across the fifteen articles in the special issue; studies have begun to differentiate between disciplines, professional learning is a key theme and potential...reflection...creativity can be seen as core themes in eportfolio integrations that span many disparate applications. Whilst support and time do need to be afforded to eportfolio practice, the authors collectively assert the benefits of eportfolio to learners.

\section{Supporting women scholars}

In May, 2020, \#FemEdTech published an Open Letter to Editors and Editorial Boards denouncing the disproportionate impact of the COVID-19 pandemic on women researchers and scholars. Since then, further accounts have emerged of the impact of the pandemic and the related lockdowns on women researchers, specifically where women in academia are publishing fewer journal articles than they were before the public health emergency of international concern (PHEIC), WHO's highest level of alarm, was announced in January 2020.

Women scholars' research has been significantly impacted by the pandemic, partly due to domestic caring responsibilities associated with school and childcare closures (Hutt, 2020). It is well documented that women academics are disproportionately responsible for childcare and household duties, more likely to be in dual-career relationships with other academics, and have more service and teaching responsibilities in Higher Education (King \& Frederickson, 2021).

In response, the editorial team acknowledged and identified actions we could take to help to mitigate such effects on women scholars. The editorial team provided the following supports to all authors: flexible deadlines and submission, supported online writing sessions and supportive, developmental feedback opportunities. As a result, this special issue contains submissions from 29 authors, of which 24 are women and 5 are men and where $97 \%$ of first authors are female. The editorial team are proud to have supported women scholars during the Covid-19 pandemic and hope that our supportive and flexible approach will serve as an example to the scholarly community.

\section{Final thoughts}

The Covid-19 pandemic exposed the cracks in our traditional approaches to assessment. During the great onlining, traditional assessment methods such as face to face examinations were no longer possible and new forms of assessment such as eportfolio were embraced. It remains to be seen whether alternative assessment methods become mainstream in the long term as face-to-face campusbased exams are bound by ritual, bureaucracy and held in disproportionate awe in higher education. This is in spite of the educational literature indicating that traditional exams are a poor measure of student learning which encourage knowledge reproduction rather than critical engagement. According to Villarroel et al. (2020, p.38) exams "tend to measure lower order thinking skills in a decontextualized manner at a time when the literature frequently argues for the benefits of a richer, authentic approach to assessment". 
What do students think? According to a recent IUA study, students preferred authentic continuous assessment to final summative exams, in fact " $84 \%$ of students would favour continuous or open book assessments over formal examinations in an ideal learning environment (EDTL, 2021)". By contrast, a DCU study reported that $55 \%$ of students reported that online assessments were more stressful than face-to-face ones (Farrell et al., 2021).

A recent study conducted by the National Forum for Teaching and Learning in Higher Education (2020) about Irish higher education teaching and learning during the pandemic found that "there is an increased appetite to re-think traditional assessment practices". While this is a welcome positive outcome of the pivot online will it come to fruition in the long term? Two significant barriers to transforming higher education assessment identified by O'Neill and Padden (2021) were a perceived lack of time and support by academics.

In order to affect long term change in the area of assessment which incorporates the voice of students and academics, there needs to be a cultural shift in our attitudes to higher education assessment and a structural shift in how we allocate academics time, space and support to enable innovation in assessment. Will the Covid-19 pandemic be the lever for this systemic change?

Eynon \& Gambino in High-Impact ePortfolio Practice: A Catalyst for Student, Faculty and Institutional Learning (2017) highlighted the potential value of eportfolio and how "ePortfolio done well" can advance student success; support reflection, and deeper learning. Many of the articles in this issue note the potential of eportfolio to support learning; how they facilitate reflection on the learning journey; and can creatively showcase skills and knowledge. The key point to consider is what is eportfolio 'done well'? The pandemic has proved a catalyst for eportfolio practice and certainly has seen an increase in eportfolio as an alternative assessment approach. It is important to ensure that integrating eportfolio is 'done well', sufficient explanation, supports and credit is afforded to their use. Without that, there is the potential for students to consider eportfolio as additional or bolted on work, without fully understanding or experiencing the manifold benefits of eportfolio.....and that would be a terrible loss. This underscores the importance of this special issue; supporting and disseminating eportfolio research and sharing the learnings from eportfolio integration so that we can all practice eportfolio 'done well'. 


\section{References}

Chen, HL., Black, T. (2010). Using eportfolio to support an undergraduate learning career: An experiment with academic advising. Educause Review. Available at https://er.educause.edu/

Costelloe, L., (2021). Exploring the potential of digital teaching portfolios to support in/non-formal professional development for those who teach in Higher Education. Irish Journal of Technology Enhanced Learning, 6(1), 113. https://doi.org/10.22554/ijtel.v6i1.72

EDTL (2021). Your Education, Your Voice, Your Vision: Results of the Student Campaign run by the Enhancing Digital Teaching and Learning project, April - May 2021.

https://edtl.blog/wpcontent/uploads/2021/08/IUA-EDTL-Your-Education-Your-VoiceYour-Vision-FullReport.pdf

Farrell, O., (2020). From Portafoglio to Eportfolio: The Evolution of Portfolio in Higher Education. Journal of Interactive Media in Education, 2020(1), p.19. DOI: http://doi.org/10.5334/jime.574

Farrell, AM, Buckley, K, Glynn, M, Lowney, R, Smyth, S, Stone, S. (2021). Moving large classes online: Illuminating the experience of the sudden transition of large, face-to-face programmes to the online environment in Dublin City University, in response to the Covid-19 crisis. Dublin City University. https://doi.org/10.5281/zenodo.4574650

Femedtech (n.d) Open Letter to Editors and Editorial Boards: An Update - femedtech. Retrieved 2 December 2021, from https://femedtech.net/published/open-letter-to-editors-and-editorial-boards-an-update/

Femedtech (n.d) Open Letter to Editors/Editorial Boards - femedtech. Retrieved 2 December 2021, from https://femedtech.net/published/open-letter-to-editors-editorial-boards/

Gallen, J. (2021). Eportfolios as Reflective Assessment of Social Justice. Irish Journal of Technology Enhanced Learning, 6(1), 22-28. https://doi.org/10.22554/ijtel.v6i1.89

Kuh, G. D. (2017). And now there are 11. In B. Eynon \& L. M. Gambino, High-impact ePortfolio practice: A catalyst for student, faculty, and institutional learning (pp. vii-xi). Sterling, VA: Stylus

McManus, R. (2021). Lessons from reflective journaling in undergraduate eportfolios. Irish Journal of Technology Enhanced Learning, 6(1), 29-36. https://doi.org/10.22554/ijtel.v6i1.81

Nagle, L, O'Connell, M., Farrelly, T. (2019): A gap in governance: acknowledging the challenges of organic ePortfolio implementation, Educational Media International. https://doi.org/10.1080/09523987.2019.1682271

O’Neill, G., Padden, L., (2021). Diversifying assessment methods: Barriers, benefits and enablers. Innovations in Education and Teaching International. https://doi-org.dcu.idm.oclc.org/10.1080/14703297.2021.1880462

Irish Journal of Technology Enhanced Learning. (n.d.). Retrieved 2 December 2021, from https://journal.ilta.ie/index.php/telji

King, M. M., Frederickson, M. E. (2021). The Pandemic Penalty: The Gendered Effects of COVID-19 on Scientific Productivity. Socius, 7, 23780231211006976. https://doi.org/10.1177/23780231211006977

Matthewman, S., Huppatz, K. (2020). A sociology of Covid-19. Journal of Sociology, 56(4), 675-683. https://doi.org/10.1177/1440783320939416

National Forum for the Enhancement of Teaching and Learning in Higher Education (2020). Reflecting and Learning: The move to remote/online teaching and learning in Irish higher education. Retrieved 2 December 2021, from https://hub.teachingandlearning.ie/wp-content/uploads/2021/06/NF-2020-Reflecting-and-Learningweb-ready.pdf 
Shankar, K., Phelan, D., Suri, V. R., Watermeyer, R., Knight, C., Crick, T. (2021). 'The COVID-19 crisis is not the core problem': Experiences, challenges, and concerns of Irish academia during the pandemic. Irish Educational Studies, 40(2), 169-175. https://doi.org/10.1080/03323315.2021.1932550

Schneider, C. G. (2018). Catalyst in action: Case studies of high-impact ePortfolio practice. Stylus Publishing, LLC.

Utoft, E. H. (2020). 'All the single ladies' as the ideal academic during times of COVID-19? Gender, Work \& Organization, 27(5), 778-787. https://doi.org/10.1111/gwao.12478

Villarroel, V., Boud, D., Bloxham, S., Bruna, D., Bruna, C. (2020). Using principles of authentic assessment to redesign written examinations and tests. Innovations in Education and Teaching International, 57(1), 38-49. doi:10.1080/14703297.2018.1564882

Ziegelbauer, C., \& D'Errico, B. (2021). ePortfolio in Teacher Education and Academic Further Education. Irish Journal of Technology Enhanced Learning, 6(1), 37-46. https://doi.org/10.22554/ijtel.v6i1.78 